ment of their yield and that the management practised affected the subsequent production of the swards based on different strains of a species. It was impossible to obtain one assessment figure to express the value of a strain relative to another when tested under different conditions; trials involving grazing had given different results from those based on cutting.

An outline of the problems of introducing new variability into cultivated oats through $6 \times$ amphidiploids and the induction of mutations was given by Dr. D. J. Griffiths. With the view of introducing genetic factors such as disease resistance into cultivated hexaploid varieties, experimental $6 \times$ amphidiploids had been produced through crossing tetraploid with diploid species followed by colchicine treatment. Representative plants from $A_{2}$ and $A_{3}$ generations of $6 \times$ amphidiploids developed from $A$. barbata $\times A$. strigosa subsp. hirtula had been crossed with natural hexaploid species as well as with other amphidiploids. The data produced on disease reactions, fertility and morphological characteristics of the $F_{1}$ generations were discussed in relation to practical breeding.

In his paper on problems of selecting for yield in oats Mr. J. D. Hayes indicated that improvements had been achieved by concentrating on major factors limiting yields such as straw length and disease reaction. Further improvement must, however, be based on increase in yield of grain, and tests capable of detecting differences of 10 per cent or less are required. A large number of replications were required at present to achieve this precision, but the error variance could be reduced in various ways. Some problems associated with early generation testing were raised; it was suggested that the area of land used for this test should be greatly increased.

Dr. D. G. Rowlands had found that Vicia faba showed cytological irregularities of a type normally associated with the inbreeding of a naturally outbreeding species; this was confirmed by controlled pollination experiments. The existence of both cross- and self-sterility has been found; inbreeding resulted in reduced pod and seed formation as well as in many sterile plants, but occasional plants produced pods and seeds satisfactorily. Although hybrid populations had shown consistent superiority over inbreds, long-term improvement of field beans must be sought through the development of self- fertile lines ; in the meantime improvement in yield may be possible by producing synthetic varieties.

Informal discussions were continued during the afternoons at demonstrations of the work of the Station in the breeding grounds, greenhouses and laboratories of the new headquarters, Gogerddan, near Aberystwyth.

Lolium multiflorum $\times$ Festuca arundinacea derivatives in which fertility had been restored by doubling the chromosome number were demonstrated. Several potential strains of grasses bred for the colder months when grass is normally scarce were shown as well as the wide range of diploid and tetraploid ecotypes of Dactylis. The work in cytology included investigations of inter- and intra-specific relationships of grasses and cytological surveys of field populations. The laboratory techniques for uncovering genetic variation in Lolium and Phleum under controlled photoperiod and temperature were illustrated and also the application of this rapid technique for strain identification. The herbage legume breeding programme included the production of higher-yielding, late-flowering red clover, larger-leaved and more persistent types of white clover and lucerne for high rainfall areas. Studies on the inheritance of flower colour in lucerne and lucerne selections for tolerance to manganese deficiency were demonstrated.

In the work on oats, emphasis was laid on improvement of yields for different levels of fertility, resistance to stem eelworm and mildew and the use of irradiation for improvement of winter varieties. The value of diallel crossing for barley and wheat breeding was under investigation. Improvement in yields and early ripening was sought in field beans. In the rape crop the chief aims were improvement in frost resistance and leafiness; the effect of hybridization on plant vigour was shown.

Studies of agronomic techniques for the assessment of herbage strains were seen and also agronomic studies of potential strains of grasses. The effects of management of grasses grown in wide drills and as clones on the subsequent seed crops were under investigation and also the effect of density on grass seed yields. Gibberellic acid was used in seedproduction studies of late-flowering red clover. Routine laboratory determinations of fibre and nitrogen contents are made for the breeders and agronomists and investigations of soil nutrients are in progress.
Gwirym Evans

\title{
THE MACAULAY INSTITUTE FOR SOIL RESEARCH
}

$\mathrm{T}$ HE main body of the annual report (1956-57) of the Mrcaulay Institute for Soil Research, Aberdeen (pp. 66; from the Institute at Craigiebuckler, Aberdeen ; 1958), is devoted to the work of the Podology Department. The soil survey of the country around Banff, Huntly and Turriff, Jedburgh and Morebattle, and Kilmarnock has been completed. The typical horizons of the seven major soil groups so far encountered are listed. (Full details will be found in the three appropriate memoirs published by the Soil Survey of Scotland.) Other sections of the Pedology Department contribute to the ecology of peat pollen analysis and Quaternary research, bog cultivation and reclamation, studies on Scottish soils, problems of phosphate fixation, rock weathering, the application of differential thermal analysis to clay mineralogy, etc.

The Department of Spectrochemistry has done collaborative work on trace elements in addition to the investigation of spectrochemical methods of analysis concerning flame, arc, spark and pulsed arc emission. Differences in the infra-red absorption spectra of di-and tri-octahedral clay minerals as well as smaller differences between individual minerals in each group have been observed. Infra-red spectrometry has also been applied to the identification of organic compounds in microbial metabolism. Modification of absorption spectra are described due to the presence of bases in alcohols and sodium ions in potass. ium bromide in ultra-violet and infra-red spectrometry. 
The work of the Biochemistry Department embraces: the lignin derivatives, carbohydrates and amino-acids in soils and peats ; the metabolism of soil micro-organisms in relation to the biological synthesis of 6-O-acetyl-D-glucopyranose and acetyl-glucose, and the $\beta$-oxidation of aliphatic hydrocarbons and herbicidal fatty acids ; and the determination of the organic acids, amino-acids and water-soluble carbohydrates in plants. A short note on special methods is also included.

The Plant Physiology Department reports work on mineral balance principally (including major element interaction and the $\mathrm{NO}_{3}^{-}: \mathrm{NH}_{4} \cdot$ effect). Respiration studies include the sensitivity of dwarf shoots of larch and cedar to potassium cyanide and the metabolism of disks of storage tissue. Measurements of the cation exchange capacity of roots under toxic levels of various metals are described. The influence of fission products fall-out on the extraneous radio- activity in samples of vegetation has also been examined.

The Department of Soil Fertility has been mainly concerned with interrelated field, pot and laboratory work on crop responses (to the major nutrients, the trace elements and magnesium) of different crops grown on the major soil types, and the distribution, composition and stability of nucleic acids in the soil organic phosphorus. In addition to collaborative work on soil micro-organisms described earlier, the Microbiology Department has investigated the growth of thermophilic actinomycetes from composts and the demethoxylation of simple aromatic compounds by soil fungi and wood-rotting basidiomycetes. A preliminary report on the role of micro-organisms of the root region in the phosphate nutrition of plants is given.

Brief accounts from the Forestry, Radioactivity and Statistics Sections are also included.

\section{AGRICULTURAL HISTORY IN HOLLAND}

$I^{N}$ $N$ England the study of agricultural history is in I the main a discipline that forms part of the departments of economic history in our various universities. For the past five years it has also been stimulated by the founding of the Agxicultural History Society. This Society was established by private enterprise, but as it numbers among its members many university personnel from all over the country, and indeed foreign countries, it has intimate relations with the academic institutions where the subject is being studied.

It is of the greatest importance in Holland, where the progress of farming has been an example and a lesson to other European countries, England in particular. In 1939 a Studiekring voor de Geschiedenis van de Landbouw was privately organized as a Department of the Koninklijk Genootschap voor Landbouwwetenschap, with headquarters at Wageningen. This Studiekring includes Belgian members as well as Dutch. It has published four volumes at intervals since its formation.

Enthusiasm for the subject waxed after the War, and led to the establishment of the Nederlands Agronomisch-Historisch Instituut: Instituut voor Landbouwgeschiedenis at Groningen. This Institute is financed jointly by the Dutch Ministry of Agriculture, the Farmers' Society, the Workers' Unions and the State University of Groningen. It is part of the academic world, and is now directed by Dr. L. S. Meihuizen. Its main work is the preparation of an annual international bibliography of current books, articles and original documents, under the title "Historia Agriculturae". The fourth volume of this publication was issued early in the current year. In addition to the bibliography, records and other important sources for Dutch agricultural history are printed in each volume. Besides this the Institute undertakes the supply of information regarding sources to students and scholars both in the Netherlands and in other countries. To facilitate this work the Institute has collected a considerable and growing library of international works and prepared an extensive documentation. When agricultural archives come to its notice the Institute arranges, when possible, for them to be deposited in the State
Archive Library, where they are cared for by the Keeper of State Archives.

In addition to the "Historia Agriculturae" other work currently being undertaken at the Institute is : (a) the collection of sixteenth- and seventeenth-century notices of orders issued by the local authorities for the regulation of farming and the marketing of produce; (b) a bibliography covering the life and conditions of employment of the Dutch farm worker ; (c) a study of the economic history of the trade in farm produce in a polder in Zeeland in the nineteenth century. A hand-list of sources for Dutch students of agricultural history is in preparation.

Last year the organization of agricultural history was strengthened by the establishment of a Department of Agricultural History at the Landbouwhogeschool at Wageningen under the direction of Prof. B. H. Slicher van Bath, formerly professor in the State University at Groningen. He will be responsible for a course in agricultural history for undergraduates, and is directing research in the social and economic history of farming in Holland. In this connexion he is editing a series of studies "Historische Sociografieën van het Platteland", the first volume of which, "Een Samenleving onder Spanning: Geschiedenis van het Platteland in Overijssel", appeared last year over his own signature. He continues to act as secretary to the directing board of the Groningen Institute.

A further activity of this Department will be the reorganization of the Agricultural Museum at Wageningen on modern museum lines and its expansion to make it the repository of a collection of early agricultural equipment, implements and tools, and form an adequate instrument for the preservation and study of such things. This work is being done by Dr. J. M. G. van der Poel, formerly director of the Groningen Institute, whose reputation is already known beyond the frontiers of Holland, and who has formulated an imposing plan for the future.

Clearly the Dutch have recognized the importance of the study of agricultural history-both the acad. emic world, the government, and the industry itself.

G. E. FUSSELI 